\title{
Pembagian Kewenangan Dalam Penegakan Hukum Terhadap Pelanggaran Peraturan Perundang-Undangan Di Perairan Indonesia
}

\author{
Abdul Muthalib Tahar dan Widya Krulinasari
}

Dosen Bagian Hukum Internasional Fakultas Hukum Universitas Lampung

\begin{abstract}
Abstrak
Sesuai dengan UU No. 6 Tahun 2006 Indonesia merupakan Negara Kepulauan. Berdasarkan Undang-undang tersebut, perairan Indonesia meliputi laut teritorial Indonesia, perairan kepulauan Indonesia, dan perairan pedalaman Indonesia. Perairan ini tunduk dan berada di bawah kedaulatan negara Indonesia. Di samping itu Negara Indonesia juga memiliki hak berdaulat atas Zona Ekonomi Eksklusif Indonesia (ZEEI) yang diatur dalam UU No. 5 Tahun 1983, dan memiliki hak berdaulat atas zona tambahan, dan landas kontinen. Perairan Indonesia merupakan sumber daya hayati (perikanan), dan daerah dasar laut dan tanah di bawahnya merupakan sumber daya non-hayati bagi bangsa Indonesia. Perairan Indonesia juga dimanfaatkan oleh kapal-kapal Indonesia dan asing untuk navigasi antar pulau maupun antar Negara. Begitu besar manfaat dan pentingnya perairan Indonesia, di perairan Indonesia seringkali terjadi pelanggaran perundangundangan yang berkaitan dengan perairan Indonesia, seperti pencurian ikan yang dilakukan oleh kapal-kapal penangkap ikan asing (illegal fishing), usaha penyelundupan barang-barang, keimigrasian, pembuangan limbah minyak dari kapal-kapal, dan lalu-lintas kapal yang tidak damai. Terhadap pelanggaran perundang-undangan ini perlu dilakukan penindakan; akan tetapi dalam upaya penindakan ini sering kali terjadi tumpang tindih kewenangan di antara berbagai instansi yang memiliki kewenangan penegakan hukum di perairan Indonesia. Hasil penelitian menunjukkan bahwa berdasarkan ketentuan UU No. 5 Tahun 1983 tentang ZEEI, bahwa satu-satunya aparatur penegak hukum di bidang penyidikan di Zona Ekonomi Eksklusif Indonesia adalah Perwira Tentara Nasional Indonesia Angkatan Laut yang ditunjuk oleh Panglima Angkatan Bersenjata Republik Indonesia. Wilayah pengelolaan perikanan Republik Indonesia untuk penangkapan ikan dan/atau pembudidayaan meliputi laut teritorial Indonesia, perairan kepulauan, dan perairan pedalaman Indonesia, serta ZEEI. Berdasarkan ketentuan UU No. 31 Tahun 2004 tentang Perikanan, secara umum ditentukan bahwa penyidikan tindak pidana di bidang perikanan dilakukan oleh Penyidik Pegawai Negeri Sipil Perikanan, Perwira TNI AL, dan Pejabat Polisi Negara Republik Indonesia. Bahwa Penyidik Pegawai Negeri Sipil Perikanan dari Dinas Kelautan dan Perikanan Propinsi hanya memiliki wewenang penegakan hukum bidang perikanan di laut teritorial (sejauh 8 mil dari batas luar laut teritorial ke sisi darat), dan di perairan kepulauan (sejauh 8 mil dari batas luar yang menjadi wewenang kabupaten). Sedangkan Penyidik Pegawai Negeri Sipil Perikanan dari Dinas Kelautan dan Perikanan Kabupaten memiliki wewenang penegakan hukum bidang perikanan di perairan pedalaman, laut teritorial (4 mil dari garis pangkal kepulauan), dan perairan kepulauan (4 mil dari garis air surut). Belum ada suatu ketentuan dalam peraturan perundang-undangan mengenai siapa
\end{abstract}


yang berwenang melakukan tindakan hukum (mengusir, menangkap dan menahan) terhadap kapal-kapal asing yang melakukan lintas di laut teritorial dan perairan kepulauan Indonesia yang membahayakan kedamaian, ketertiban, atau keamanan Indonesia, sebagaimana ditentukan dalam KHL 1982 Pasal 19. Bahwa yang berwenang melaksanakan penegakan hukum di zona tambahan dan di perairan kepulauan terhadap kapal dan orang yang melakukan pelanggaran terhadap perundang-undangan bea dan cukai, sesuai dengan UU No. 7 Tahun 2006 tentang Kepabeanan adalah penyidik pegawai negeri sipil pada Direktorat Bea dan Cukai; untuk pelanggaran keimigrasian dan fiskal adalah penyidik pegawai negeri sipil pada Direktorat Keimigrasian; untuk pelanggaran sanitasi adalah penyidik pegawai negeri sipil di Kementerian Kesehatan; sedangkan untuk perompakan di laut adalah polisi perairan (Polair).

\section{Pendahuluan}

Berdasarkan KHL 1982 dan UU No. 6 Tahun 1996 tentang Perairan Indonesia, Negara Indonesia adalah Negara kepulauan. Berdasarkan ketentuan ini perairan Indonesia meliputi laut teritorial Indonesia, perairan kepulauan Indonesia, dan perairan pedalaman Indonesia. Perairan ini menurut ketentuan UU tunduk dan berada di bawah kedaulatan negara Indonesia. Di samping itu Negara Indonesia juga memiliki hak berdaulat atas Zona Ekonomi Eksklusif Indonesia (ZEEI) yang diatur dalam UU No. 5 Tahun 1983, dan memiliki hak berdaulat atas zona tambahan, dan landas kontinen.

Perairan Indonesia dan ZEEI daerah perairannya merupakan sumber daya hayati (perikanan), daerah dasar laut dan tanah di bawahnya merupakan sumber daya non hayati yang bermanfaat sebagai sumber mata pencaharian penduduk pantai (nelayan) dan sebagai sumber devisa Negara. Di samping itu perairan Indonesia dimanfaatkan untuk berbagai kepentingan antara lain sebagai lalu lintas kapal, dan sebagai sarana melakukan riset ilmiah kelautan.
Begitu besar manfaat dan pentingnya perairan Indonesia, maka di perairan Indonesia seringkali terjadi pelanggaran perundangundangan yang berkaitan dengan perairan Indonesia ini, pencurian ikan yang dilakukan oleh kapal-kapal penangkap ikan asing (illegal fishing), usaha penyelundupan barang-barang, keimigrasian, pembuangan limbah minyak dari kapal-kapal, dan lalu-lintas kapal yang tidak damai. Terhadap pelanggaran perundang-undangan ini perlu dilakukan penindakan; akan tetapi dalam upaya penindakan ini sering kali terjadi tumpang tindih kewenangan di antara berbagai instansi yang memiliki kewenangan penegakan hukum di perairan Indonesia. Berkaitan dengan hal tersebut dalam penelitian ini ini yang menjadi permasalahan adalah : Peraturan perundang-undangan apa saja yang substansinya mengatur penegakan hukum terhadap pelanggaran hukum di perairan Indonesia ? dan Siapa saja yang berwenang melakukan penegakan hukum di perairan Indonesia ? Guna menjawab permasalahan ini peneliti melakukan penelitian yuridis normatif menggunakan tipe penelitian deskriptif analitis, 
menggunakan data sekunder yang hasilnya sebagai berikut :

\section{Peraturan Perundang-undangan yang Berlaku dalam Penegakan hukum di Zona Ekonomi Eksklusif Indonesia}

\section{Zona Ekonomi Eksklusif} Indonesia (ZEEI) menurut UU No. 5 Tahun 1983 adalah "jalur di luar dan berbatasan dengan laut wilayah Indonesia sebagaimana ditetapkan berdasarkan undang-undang yang berlaku tentang perairan Indonesia yang meliputi dasar laut, tanah di bawahnya dan air di atasnya dengan batas terluar 200 (dua ratus) mil laut diukur dari garis pangkal laut wilayah Indonesia".

Akan tetapi lebar sesungguhnya zona ini adalah 188 mil laut, karena 12 mil laut dari garis pangkal (garis pangkal lurus kepulauan, garis pangkal biasa atau garis pangkal lurus) merupakan laut teritorial yang tunduk di bawah kedaulatan Negara Republik Indonesia.

Di perairan zona ekonomi eksklusif terdapat kebebasan pelayaran bagi kapal-kapal asing, sedangkan ruang udara di atas zona ekonomi eksklusif terdapat kebebasan penerbangan bagi pesawat-pesawat terbang negara asing.

Di ZEEI, Republik Indonesia mempunyai dan melaksanakan :

a. Hak berdaulat untuk melakukan eksplorasi dan eksploitasi, pengelolaan dan konservasi smber daya alam hayati dan non hayati dari dasar laut dan tanah di bawahnya serta air di atasnya dan kegiatan-kegiatan lainnya untuk ekplorasi dan eksploitasi ekonomis zona tersebut, seperti pembangkitan tenaga dari air, arus, dan angin;

b. Yurisdiksi berhubungan yang berhubungan dengan :

(1) pembuatan dan penggunaan pulau-pulau buatan, instalasiinstalasi dan bangunanbangunan lainnya;

(2) penelitian ilmiah mengenai kelautan;

(3) perlindungan dan pelestarian lingkungan laut

c. Hak-hak lain dan kewajibankewajiban lainya berdasarkan Konvensi Hukum Laut yang berlaku (KHL 1982). ${ }^{1}$

Adapun perbuatan-perbuatan atau tindakan-tindakan yang masuk kategori kejahatan di ZEEI menurut UU No. 5 Tahun 1983 ini adalah :

a. Melakukan eksplorasi dan/atau eksploitasi sumber daya alam atau kegiatan-kegiatan lainnya untuk eksplorasi dan/atau eksploitasi ekonomis seperti pembangkitan tenaga dari air, arus dan angin di Zona Ekonomi Eksklusif Indonesia, tanpa izin dari Pemerintah Republik Indonesia atau berdasarkan persetujuan internasional dengan Pemerintah Republik Indonesia dan dilaksanakan menurut syaratsyarat perizinan atau persetujuan internasional. $^{2}$

b. Membuat dan/atau menggunakan pulau-pulau buatan atau instalasiinstalasi atau bangunan-bangunan lainnya di Zona Ekonomi Eksklusif Indonesia tanpa izin dari Pemerintah Republik Indonesia. $^{3}$

c. Melakukan kegiatan penelitian ilmiah di Zona Ekonomi Eksklusif Indonesia tidak

\footnotetext{
${ }^{1}$ UU ZEEI Pasal 4 ayat (1)

${ }^{2}$ Ibid Pasal 5 ayat (1)

${ }^{3}$ Ibid Pasal 6.
} 
memperoleh persetujuan terlebih dahulu dari dan dilaksanakan berdasarkan syarat-syarat yang ditetapkan oleh Pemerintah Republik Indonesia.

d. Melakukan tindakan-tindakan yang menyebabkan rusaknya lingkungan hidup dan/atau tercemarnya lingkungan hidup dalam Zona Ekonomi Eksklusif Indonesia. ${ }^{4}$ Diancam dengan pidana sesuai dengan peraturan perundang-undangan yang berlaku di bidang lingkungan hidup.

Mengenai penegakan hukum di ZEEI, UU No. 5 Tahun 1983 Pasal 13 menentukan, bahwa dalam rangka melaksanakan hak berdaulat, hak-hak lain, yurisdiksi dan kewajibankewajiban sebagaimana dimaksud dalam Pasal 4 ayat (1), aparatur penegak hukum Republik Indonesia yang berwenang, dapat mengambil tindakan-tindakan penegakan hukum sesuai dengan Undang-undang Nomor 8 Tahun 1981 tentang Kitab Undang-undang Hukum Acara Pidana, dengan pengecualian sebagai berikut :

(a) Penangkapan terhadap kapal dan/atau orang-orang yang diduga melakukan pelanggaran di Zona Ekonomi Eksklusif Indonesia meliputi tindakan penghentian kapal sampai dengan diserahkannya kapal dan/atau orang-orang tersebut dipelabuhan dimana perkara tersebut dapat diproses lebih lanjut;

(b) Penyerahan kapal dan/atau orang-orang tersebut harus dilakukan secepat mungkin dan tidak boleh melebihi jangka waktu 7 (tujuh) hari, kecuali

\footnotetext{
${ }^{4}$ Ibid Pasal 16 ayat (3).
}

apabila terdapat keadaan force majeure;

(c) Untuk kepentingan penahanan, tindak pidana yang diatur dalam Pasal 16 dan Pasal 17 termasuk dalam golongan tindak pidana sebagaimana dimaksud dalam Pasal 21 ayat (4) huruf b Undang-undang Nomor 8 Tahun 1981 tentang Kitab Undangundang Hukum Acara Pidana.

Mengenai siapa yang menjadi penegak hukum di ZEEI, Pasal 14 menentukan sebagai berikut :

(1) Aparatur penegak hukum di bidang penyidikan di Zona Ekonomi Eksklusif Indonesia adalah Perwira Tentara Nasional Indonesia Angkatan Laut yang ditunjuk oleh Panglima Angkatan Bersenjata Republik Indonesia.

(2) Penuntut umum adalah jaksa pada pengadilan negeri sebagaimana dimaksud dalam ayat (3).

(3) Pengadilan yang berwenang mengadili pelanggaran terhadap ketentuan undang-undang ini adalah pengadilan negeri yang daerah hukumnya meliputi pelabuhan dimana dilakukan penahanan terhadap kapal dan/atau orang-orang sebagaimana dimaksud dalam Pasal 13 huruf a.

Mengenai permohonan pembebasan kapal dan/atau orang yang ditangkap karena didakwa melakukan pelanggaran terhadap UU ZEEI, diatur dalam Pasal 15 yang menentukan sebagai berikut :

(1) Permohonan untuk membebaskan kapal dan/atau orang-orang yang ditangkap karena didakwa melakukan pelanggaran terhadap undang-undang ini atau peraturan perundang-undangan yang dikeluarkan berdasarkan undang- 
undang ini, dapat dilakukan setiap waktu sebelum ada keputusan dari pengadilan negeri yang berwenang.

(2) Permohonan untuk pembebasan sebagaimana dimaksud dalam ayat(1),dapat dikabulkan jika pemohon sudah menyerahkan sejumlah uang jaminan yang layak, yang penetapannya dilakukan oleh pengadilan negeri yang berwenang.

Ketentuan lain yang berkaitan dengan eksploitasi sumber daya hayati di ZEEI diatur dalam UU No. 31 Tahun 2004 tentang Perikanan. Menurut UU Perikanan ini wilayah pengelolaan perikanan Republik Indonesia untuk penangkapan ikan dan/atau pembudidayaan ikan meliputi :

a. Perairan Indonesia;

b. Zona ekonomi eksklusif Indonesia; dan

c. Sungai, danau, waduk, rawa, dan genangan air lainnya yang dapat diusahakan, serta lahan pembudidayaan ikan yang potensial di wilayah Repubilik Indonesia. ${ }^{5}$

Apabila ketentuan ini kita hubungkan dengan ketentuan Pasal 3 ayat (1) UU No. 6 Tahun 1996 tentang Perairan Indonesia, maka wilayah pengelolaan perikanan Republik Indonesia untuk penangkapan ikan dan/atau pembudidayaan meliputi laut teritorial Indonesia, perairan kepulauan, dan perairan pedalaman Indonesia.

Adapun larangan bagi kapalkapal penangkap ikan asing ditentukan sebagai berikut :

(1) Setiap kapal penangkap ikan berbendera asing yang tidak

\footnotetext{
${ }^{5}$ UU No. 31 Tahun 2004 Pasal 5.
}

memiliki izin penangkapan ikan selama berada di wilayah pengelolaan perikanan Republik Indonesia wajib menyimpan alat penangkap ikan di palka;

(2) Setiap kapal penangkap ikan berbendera asing yang telah memiliki izin penangkapan ikan dengan satu jenis alat penangkap ikan tertentu pada bagian tertentu di ZEEI dilarang membawa alat penangkap ikan lainnya;

(3) Setiap kapal penangkap ikan berbendera asing yang telah memiliki izin penangkapan ikan wajib menyimpan alat penangkapan ikan di dalam palka selama berada di luar daerah penangkapan ikan yang diizinkan di wilayah pengelolaan perikanan Republik Indonesia. ${ }^{6}$

Di dalam UU Perikanan diatur berbagai hal yang berkaitan dengan penegakan UU Perikanan, antara lain Penyidikan. Penyidikan tindak pidana di bidang perikanan dilakukan oleh Penyidik Pegawai Negeri Sipil Perikanan, Perwira TNI AL, dan Pejabat Polisi Negara Republik Indonesia. Di antara mereka dapat melakukan koordinasi, dan untuk melakukan koordinasi dalam penanganan tindak pidana di bidang perikanan, Menteri Kelautan dan Perikanan dapat membentuk forum koordinasi. ${ }^{7}$ Selanjutnya Berdasarkan UU Perikanan ini juga dibentuk Pengadilan Perikanan. Pengadilan Perikanan untuk pertama kali dibentuk di Pengadilan Negeri Jakarta Utara, Medan, Pontianak, Bitung, dan Tual.

Beberapa tindak pidana yang dapat diadili di Pengadilan Perikanan diatur dalam pasal 84 s/d 102. Di

\footnotetext{
${ }^{6}$ Idem Pasal 38.

${ }^{7}$ Idem, Pasal 73
} 
mana tindak pidana yang diatur dalam pasal $84,85,86,88$, pasal 91, 92, 93, dan 94 adalah kejahatan. Sedangkan tindak pidana yang diatur dalam pasal 95, 96, 97, 98, 99, dan pasal 100 adalah pelanggaran.

Berkaitan dengan penegakan UU Perikanan ini timbul permasalahan, yaitu apakah Penyidik Pegawai Negeri Sipil Perikanan dari Dinas Perikanan dan Kelautan (DPK) Propinsi atau Kabupaten memiliki kewenangan melakukan penangkapan terhadap illegal fishing di laut teritorial Indonesia dan ZEEI ?

Guna menjawab permasalahan tersebut kita harus melihat ketentuan dalam UU No. 32 Tahun 2004 tentang Pemerintahan Daerah. Pasal 18 UU ini menentukan bahwa Daerah yang memiliki wilayah laut diberikan kewenangan untuk mengelola sumber daya di wilayah laut. $^{8}$ Daerah mendapatkan bagi hasil atas pengelolaan sumber daya alam di bawah dasar dan/atau di dasar laut sesuai dengan peraturan perundangundangan. ${ }^{\text {' Kewenangan daerah untuk }}$ mengelola sumber daya di wilayah laut meliputi : (a) eksplorasi, eksploitasi, konservasi, dan pengelolaan kekayaan laut; (b) pengaturan administratif; (c) pengaturan tata ruang; (d) penegakan hukum terhadap peraturan yang dikeluarkan oleh daerah atau yang dilimpahkan kewenangannya oleh Pemerintah; (e) ikut serta dalam pemeliharaan keamanan; dan (f) ikut serta dalam pertahanan kedaulatan negara. ${ }^{10}$

Selanjutnya ditentukan bahwa kewenangan untuk mengelola sumber daya di wilayah laut sebagaimana dimaksud pada ayat (3) paling jauh 12 (dua belas) mil laut diukur dari garis pantai ke arah laut lepas dan/atau ke

\footnotetext{
${ }^{8}$ UU No. 32 Tahun 2004 Pasal 18 ayat (1).

${ }^{9}$ Ibid ayat (2).

${ }^{10}$ Ibid ayat (3)
}

arah perairan kepulauan untuk provinsi dan $1 / 3$ (sepertiga) dari wilayah kewenangan provinsi untuk kabupaten/kota. ${ }^{11}$

Menurut penulis ketentuan ini menunjukkan bahwa kewenangan propinsi dan kabupaten untuk mengelola sumber daya di wilayah laut hanya terbatas di perairan kepulauan dan laut teritorial, tidak mencakup/meliputi ZEEI. Mengapa demikian karena jelas dari ketentuan Pasal 18 ayat (4) ini bahwa kewenangan propinsi dan kabupaten di wilayah laut diukur dari garis pantai ke arah laut lepas dan/atau ke arah perairan kepulauan. Di samping itu berdasarkan ketentuan UU No. 6 Tahun 1996 bahwa laut teritorial Indonesia, zona tambahan Indonesia, dan ZEEI diukur dari garis pangkal lurus kepulauan Indonesia.

Apabila ada satu atau lebih pulau yang menjadi bagian propinsi dan kabupaten yang letaknya berhadapan dengan laut lepas atau negara tetangga, dan pulau tersebut digunakan sebagai titik pangkal untuk menarik garis pangkal lurus kepulauan, maka propinsi dan kabupaten memiliki kewenangan mengelola sumber daya di laut teritorial. Sedangkan ZEEI status perairannya berada di luar laut teritorial Indonesia.

Berdasarkan argumentasi tersebut di atas, disimpulkan bahwa aparat penyidik pegawai negeri sipil DPK propinsi dan kabupaten hanya memiliki kewenangan menegakkan peraturan yang dikeluarkan oleh daerah atau yang dilimpahkan kewenangannya oleh Pemerintah di laut teitorial dan perairan kepulauan; sedangkan di ZEEI tidak memiliki kewenangan melakukan penangkapan terhadap illegal fishing yang dilakukan oleh kapal-kapal perikanan asing.

${ }^{11}$ Ibid ayat (4) 
Dengan demikian yang berwenang melakukan penegakan hukum terhadap pelanggaran UU Perikanan di ZEEI terutama oleh kapal-kapal perikanan asing terbatas pada Penyidik Pegawai Negeri Sipil Perikanan Kementerian Kelautan dan Perikanan, Perwira TNI AL, dan Pejabat Polisi Negara Republik Indonesia.

\section{Peraturan Perundang-undangan yang Berlaku dalam Penegakan hukum di Laut Teritorial Indonesia, Perairan Kepulauan Indonesia, dan Zona Tambahan}

\section{a. Peraturan Perundang-undangan yang Berlaku dalam Penegakan hukum di Laut Teritorial Indonesia dan Perairan Kepulauan Indonesia.}

Laut Territorial Indonesia adalah jalur laut selebar 12 (dua belas) mil laut yang diukur dari garis pangkal kepulauan Indonesia. Sedangkan perairan kepulauan Indonesia adalah semua perairan yang terletak pada sisi dalam dari garis pangkal lurus kepulauan Indonesia, tanpa memandang kedalaman laut dan jaraknya dari pantai. Laut teritorial Indonesia dan perairan kepulauan Indonesia, ruang udara di atas laut teritorial dan perairan kepulauan Indonesia, serta daerah dasar laut dan tanah di bawahnya tunduk di bawah kedaulatan Negara Indonesia.

Di laut teritorial Indonesia dan di perairan kepulauan Indonesia terdapat hak lintas damai bagi kapalkapal asing. Hal ini dapat dilihat pada UU No. 6 Tahun 1996 Pasal 11 ayat (1) yang menentukan bahwa kapal semua negara, baik negara pantai maupun negara tak berpantai, menikmati hak lintas damai melalui laut teritorial dan perairan kepulauan Indonesia.

Pengertian lintas berarti navigasi melalui laut teritorial dan perairan kepulauan Indonesia untuk keperluan :

a. melintasi laut tersebut tanpa memasuki perairan pedalaman atau singgah di tempat berlabuh di tengah laut atau fasilitas pelabuhan di luar perairan pedalaman; atau

b. berlalu ke atau dari perairan pedalaman atau singgah di tempat berlabuh di tengah laut ${ }_{12}$ atau fasilitas pelabuhan tersebut.

Bahwa lintas damai harus terus-menerus, langsung serta secepat mungkin, mencakup berhenti atau buang jangkar sepanjang hal tersebut berkaitan dengan navigasi yang normal, atau perlu dilakukan karena keadaan memaksa, mengalami kesulitan, memberi pertolongan kepada orang, kapal atau pesawat udara yang dalam bahaya atau kesulitan. ${ }^{13}$

Selanjutnya pengertian lintas damai ditemukan dalam Pasal 12, yang menentukan:

(1) Lintas dianggap damai apabila tidak merugikan kedamaian, ketertiban, atau keamanan Indonesia, dan dilakukan sesuai dengan ketentuan Konvensi dan hukum internasional lainnya.

(2) Lintas oleh kapal asing harus dianggap membahayakan kedamaian, ketertiban, atau keamanan Indonesia, apabila kapal tersebut sewaktu berada di laut teritorial dan atau di perairan kepulauan melakukan salah satu kegiatan yang dilarang oleh

\footnotetext{
${ }^{12}$ UU No. 6 Tahun 1996 Pasal 11 ayat (2)

${ }^{13}$ Ibid ayat (3).
} 
Konvensi dan atau hukum internasional lainnya.

Ketentuan lebih lanjut mengenai lintas damai ini diatur dalam Peraturan Pemerintah No. 36 Tahun 2002

Mengenai "kegiatan yang dilarang oleh Konvensi" sebagaimana ditentukan dalam Pasal 12 ayat (2), penjelasan pasal ini menentukan sebagai berikut :

a. setiap ancaman atau penggunaan kekerasan terhadap kedaulatan, keutuh-an wilayah atau kemerdekaan politik negara pantai,atau dengan cara lain apapun yang merupakan pelanggaran asas hukum internasional sebagaimana tercantum dalam Piagam Perserikatan Bangsa-Bangsa;

b. setiap latihan atau praktek senjata apapun;

c. setiap perbuatan yang bertujuan untuk mengumpulkan informasi yang merugikan bagi pertahanan atau keamanan negara pantai;

d. setiap perbuatan propaganda yang bertujuan mempengaruhi pertahanan atau keamanan negara pantai;

e. peluncuran, pendaratan, atau penerimaan setiap pesawat udara;

f. peluncuran, pendaratan, atau penerimaan setiap peralatan dan perlengkapan militer;

g. bongkar atau muat setiap komoditi, mata uang atau orang secara bertentangan dengan peraturan perundang-undangan bea cukai,fiskal, imigrasi, atau saniter negara pantai;

h. setiap perbuatan pencemaran dengan sengaja dan parah yang bertentangan dengan Konvensi;

i. setiap kegiatan perikanan;

j. kegiatan riset atau survei; k. setiap perbuatan yang bertujuan mengganggu setiap sistem komunikasi atau setiap fasilitas atau instalasi lainnya negara pantai; atau

1. setiap kegiatan lainnya yang tidak berhubungan langsung dengan lintas. $^{14}$

Persoalannya adalah apabila dalam melaksanakan hak lintas damai kapal-kapal asing tersebut melakukan salah satu kegiatan yang dilarang oleh Konvensi, siapakah yang berwenang menegakkannya? Tindakan-tindakan apa yang harus dilakukan.

Terhadap masalah tersebut memang belum terdapat pengaturan secara jelas. Dalam hal ini penulis berpendapat sebagai berikut :

(1) apabila kapal-kapal asing dalam lintasannya melakukan kegiatan-kegiatan yang dilarang konvensi (point a, b, c, $\mathrm{d}$, e, dan f), maka yang berwenang melakukan tindakan pengusiran adalah TNI Angkatan Laut. Karena TNI AL-lah yang memiliki sarana dan prasarana yang memadai untuk melakukan operasi rutin menjaga dan memelihara kedaulatan wilayah Indonesia di laut.

(2) apabila kapal-kapal asing dalam lintasannya melakukan kegiatan-kegiatan yang dilarang konvensi (point g), maka yang berwenang melakukan tindakan penangkapan dan penahanan adalah penyidik pegawai negeri sipil Direktorat Bea dan Cukai. Hal ini sesuai dengan UU No. 7 Tahun 2006 pasal 1 ke 1, yang menentukan bahwa daerah

\footnotetext{
${ }^{14}$ Ibid Penjelasan Pasal 12 ayat (2).
} 
pabean adalah wilayah Republik Indonesia yang meliputi wilayah darat, perairan dan ruang udara di atasnya, serta tempat-tempat tertentu di Zona Ekonomi Eksklusif dan landas kontinen yang di dalamnya berlaku UndangUndang ini. Kewenangan penyidik pegawai negeri sipil Direktorat Bea dan Cukai ini diatur dalam Pasal 112 ayat (1).

(3) apabila kapal-kapal asing dalam lintasannya melakukan kegiatan-kegiatan yang dilarang konvensi (point $\mathrm{h}$, pencemaran yang disengaja dan parah, dan k, yaitu setiap perbuatan yang bertujuan mengganggu setiap sistem komunikasi atau setiap fasilitas atau instalasi lainnya negara pantai ), maka yang berwenang melakukan penegakan peraturan perundang-undangan di laut dan pantai adalah Penjaga laut dan Pantai. ${ }^{15}$ Penjaga laut dan pantai dalam melaksanakan fungsi keselamatan dan keamanan di laut melaksanakan tugas:

a. melakukan pengawasan keselamatan dan keamanan pelayaran;

${ }^{15}$ UU No. 7 Tahun 2008 tentang Pelayaran, Pasal 276 menenukan sebagai berikut : (1) Untuk menjamin terselenggaranya keselamatan dan keamanan di laut dilaksanakan fungsi penjagaan dan penegakan peraturan perundang-undangan di laut dan pantai.

(2) Pelaksanaan fungsi sebagaimana dimaksud pada ayat (1) dilakukan oleh penjaga laut dan pantai.

(3) Penjaga laut dan pantai sebagaimana dimaksud pada ayat (2) dibentu(1) Untuk k dan bertanggung jawab kepada Presiden dan secara teknis operasional dilaksanakan oleh Menteri.
b. melakukan pengawasan, pencegahan, dan penanggulangan pencemaran di laut;

c. pengawasan dan penertiban kegiatan serta lalu lintas kapal;

d. pengawasan dan penertiban kegiatan salvage, pekerjaan bawah air, serta eksplorasi dan eksploitasi kekayaan laut;

e. pengamanan Sarana Bantu Navigasi-Pelayaran; dan

f. mendukung pelaksanaan kegiatan pencarian dan pertolongan jiwa di laut. ${ }^{16}$

Di samping itu penjaga laut dan pantai mempunyai kewenangan untuk:

a. melaksanakan patroli laut;

b. melakukan pengejaran seketika (hot pursuit);

c. memberhentikan dan memeriksa kapal di laut; dan d. melakukan penyidikan. ${ }^{17}$ Dalam melaksanakan kewenangan sebagaimana dimaksud pada ayat (1) huruf $\mathrm{d}$ penjaga laut dan pantai melaksanakan tugas sebagai pejabat Penyidik Pegawai Negeri Sipil sesuai dengan ketentuan peraturan perundangundangan. ${ }^{18}$ Ketentuan lebih lanjut mengenai kewenangan penjaga laut dan pantai diatur dengan Peraturan Pemerintah. ${ }^{19}$

(4) apabila kapal-kapal asing dalam lintasannya melakukan kegiatan-kegiatan yang dilarang konvensi (point i, yaitu kegiatan perikanan, dan $\mathrm{j}$ yaitu kegiatan riset dan survey),

\footnotetext{
${ }^{16}$ Ibid Pasal 277 ayat (1)

${ }^{17}$ Ibid Pasal 278 ayat (1)

${ }^{18}$ Ibid Pasal 278 ayat (2)

${ }^{19}$ Ibid ayat (3).
} 


\begin{abstract}
maka yang berwenang melakukan tindakan penangkapan dan penahanan adalah adalah penyidik pegawai negeri sipil DPK Propinsi dan Kabupaten.
\end{abstract}

Selanjutnya masih dalam kaitannya dengan lintas ini UU No. 6 Tahun 1996 Pasal 15 menentukan bahwa dalam melaksanakan hak lintas damai di laut teritorial dan perairan kepulauan, kapal selam dan kendaraan bawah air lainnya diharuskan melakukan navigasi di atas permukaan air dan menunjukkan bendera kebangsaan. Apabila kapal selam asing tersebut tidak memenuhi ketentuan ini maka lintas yang dilakukannya dianggap tidak damai, dan kapal tersebut diperingatkan untuk segera meninggalkan perairan Indonesia. Ketentuan ini merupakan penerapan dari Pasal 20 Konvensi. ${ }^{20}$

\section{b. Peraturan Perundang-undangan yang Berlaku dalam Penegakan hukum di Zona Tambahan.}

Di samping itu Negara Indonesia juga memiliki hak berdaulat atas suatu bagian perairan yang dinamakan zona tambahan. Zona ini lebarnya adalah 24 mil laut yang diukur dari garis pangkal. Status dan eksistensi zona tambahan ini berada di 12 mil laut teritorial Indonesia, dan 12 mil di ZEEI. Di zona tambahan negara Indonesia memiliki kewenangan terbatas, yaitu mencegah terjadinya pelanggaran perundang-undangan yang berkaitan dengan bea, cukai, fiskal, keimigrasian, dan sanitasi; serta memiliki kewenangan memberi hukuman terhadap para pelanggar-

\footnotetext{
${ }^{20}$ UU No. 6/1996, penjelasan pasal 15.
}

pelanggar ketentuan ini. Pertanyaan yang timbul adalah siapakah yang berwenang melakukan penegakan hukum di zona tambahan ini ?

Menurut pendapat penulis, bahwa yang berwenang melaksanakan penegakan hukum terhadap kapal dan orang yang melakukan pelanggaran terhadap perundangundangan bea dan cukai, adalah penyidik pegawai negeri sipil pada Direktorat Bea dan Cukai; untuk pelanggaran keimigrasian dan fiskal adalah penyidik pegawai negeri sipil pada Direktorat Keimigrasian; sedangkan untuk pelanggaran sanitasi adalah penyidik pegawai negeri sipil di Kementerian Kesehatan.

\section{Simpulan}

1. Berdasarkan ketentuan UU No. 5 Tahun 1983 tentang ZEEI, bahwa satu-satunya aparatur penegak hukum di bidang penyidikan di Zona Ekonomi Eksklusif Indonesia adalah Perwira Tentara Nasional Indonesia Angkatan Laut yang ditunjuk oleh Panglima Angkatan Bersenjata Republik Indonesia.

2. Wilayah pengelolaan perikanan Republik Indonesia untuk penangkapan kepulauan, dan perairan pedalaman Indonesia, serta ZEEI. Berdasarkan ketentuan UU No. 31 Tahun 2004 tentang Perikanan, secara umum ditentukan bahwa penyidikan tindak pidana di bidang perikanan dilakukan oleh Penyidik Pegawai Negeri Sipil Perikanan, Perwira TNI AL, dan Pejabat Polisi Negara Republik Indonesia.

3. Penyidik Pegawai Negeri Sipil Perikanan dari Dinas Kelautan 
dan Perikanan Propinsi hanya memiliki wewenang penegakan hukum bidang perikanan di laut teritorial (sejauh 8 mil dari batas luar laut teritorial ke sisi darat), dan di perairan kepulauan (sejauh 3 mil dari batas luar yang menjadi wewenang kabupaten). Sedangkan Penyidik Pegawai Negeri Sipil Perikanan dari Dinas Kelautan dan Perikanan Kabupaten memiliki wewenang penegakan hukum bidang perikanan di perairan pedalaman, laut teritorial (4 mil dari garis pangkal kepulauan), dan perairan kepulauan (4 mil dari garis air surut).

4. Belum ada suatu ketentuan dalam peraturan perundang-undangan mengenai siapa yang berwenang melakukan tindakan hukum (mengusir, menangkap dan menahan) terhadap kapal-kapal asing yang melakukan lintas di laut teritorial dan perairan kepulauan Indonesia yang membahayakan kedamaian, ketertiban, atau keamanan Indonesia, sebagaimana ditentukan dalam KHL 1982 Pasal 19.

5. Bahwa yang berwenang melaksanakan penegakan hukum di zona tambahan dan di perairan kepulauan terhadap kapal dan orang yang melakukan pelanggaran terhadap perundangundangan bea dan cukai, sesuai dengan UU No. 7 Tahun 2006 tentang Kepabeanan adalah penyidik pegawai negeri sipil pada Direktorat Bea dan Cukai; untuk pelanggaran keimigrasian dan fiskal adalah penyidik pegawai negeri sipil pada Direktorat Keimigrasian; sedangkan untuk pelanggaran sanitasi adalah penyidik pegawai negeri sipil di Kementerian Kesehatan.

\section{Saran}

1. Sesuai dengan ketentuan UU ZEEI, maka aparatur penegak hukum untuk melakukan pengawasan dan penegakan hukum terhadap pelanggaran perundang-undangan di Zona Ekonomi Eksklusif Indonesia (termasuk pelanggaran UU No. 31 Tahun 2004 tentang Perikanan) adalah Perwira Tentara Nasional Indonesia Angkatan Laut yang ditunjuk oleh Panglima Angkatan Bersenjata Republik Indonesia.

2. Pengawas Perikanan dan Penyidik Pegawai Negeri Sipil Dinas Perikanan dan Kelautan (DPK) Propinsi dan Kabupaten, sesuai dengan peraturan perundang-undangan hanya diberikan kewenangan melakukan pengawasan, penangkapan, dan penyidikan terhadap kapal-kapal perikanan yang melanggar UU No. 31 Tahun 2004 di wilayah pengelolaan perikanan di laut teritorial dan perairan kepulauan. Sedangkan untuk Kabupaten termasuk di perairan pedalaman.

3. Wewenang melakukan tindakan hukum (mengusir, menangkap dan menahan) terhadap kapalkapal asing yang melakukan lintas di laut teritorial dan perairan kepulauan Indonesia yang membahayakan kedamaian, ketertiban, atau keamanan Indonesia, sebagaimana ditentukan dalam KHL 1982 Pasal 19 (khususnya setiap ancaman atau penggunaan 
kekerasan terhadap kedaulatan kedaulatan, keutuhan wilayah atau kemerdekaan politik negara pantai, atau dengan cara lain apapun yang merupakan pelanggaran asas hukum internasional sebagaimana tercantum dalam Piagam Perserikatan Bangsa-Bangsa; setiap latihan atau praktek senjata apapun; setiap perbuatan yang bertujuan untuk mengumpulkan informasi yang merugikan bagi pertahanan atau keamanan negara pantai; setiap perbuatan propaganda yang bertujuan mempengaruhi pertahanan atau keamanan negara pantai; peluncuran, pendaratan, atau penerimaan setiap pesawat udara; dan peluncuran, pendaratan, atau penerimaan setiap peralatan dan perlengkapan militer; wewenangnya diberikan kepada TNI Angkatan Laut. Karena TNI AL-lah yang memiliki sarana dan prasarana yang memadai untuk melakukan operasi rutin menjaga dan memelihara kedaulatan wilayah Indonesia di laut.

4. Terhadap kapal-kapal asing yang dalam lintasannya di laut teritorial dan perairan kepulauan melakukan kegiatan-kegiatan yang dilarang konvensi (yaitu pencemaran yang disengaja dan parah, dan setiap perbuatan yang bertujuan mengganggu setiap sistem komunikasi atau setiap fasilitas atau instalasi lainnya negara pantai), maka yang berwenang melakukan penegakan peraturan perundang-undangan di laut dan pantai adalah Penjaga laut dan Pantai.

5. Terhadap kapal-kapal asing yang dalam lintasannya di laut teritorial dan perairan kepulauan melakukan kegiatan-kegiatan yang dilarang konvensi (yaitu kegiatan perikanan, dan kegiatan riset dan survey), maka yang berwenang melakukan tindakan penangkapan dan penahanan adalah adalah penyidik pegawai negeri sipil DPK Propinsi dan Kabupaten.

6. Kewenangan dari masing-masing instansi ini hendaknya diatur lebih lanjut dalam peraturan perundang-undangan.

7. Organisasi dan Struktur Penjaga Laut dan Pantai hendaknya segera diatur dengan Peaturan Pemerintah.

\section{DAFTAR PUSTAKA}

Djajaatmadja, Bambang Iriana, 2007.

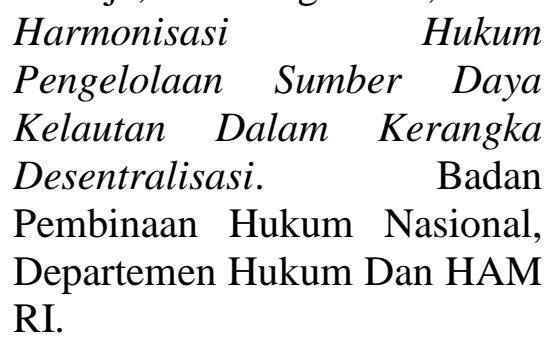

Kusumaatmadja, Mochtar, 1978. Pengantar Hukum Laut Indonesia, Binacipta, Bandung. Muhjiddin, Atje Misbach, 1989. Status Hukum Perairan Kepulauan Indonesia dan Hak Lintas Kapal Asing. Alumni, Bandung.

Kantaatmadja, Komar, 1981. Ganti Rugi Internasional Pencemaran Minyak di Laut. Alumni, Bandung.

R. Agus, Etty, 1986. Masalah Pengaturan Hak Lintas Kapal Asing. Binacipta, Bandung.

Tahar, Abdul Muthalib, dkk, 2008. Penegakan Hukum Terhadap Pelanggaran Peraturan 
Perundang undangan Perikanan di Indonesia (Laporan Penelitian).

2010. Zona-zona Maritim Menurut KHL 1982 dan Perkembangan Hukum Laut Indonesia, Buku Ajar, 2010.

Depertemen Luar Negeri R.I. Konvensi PBB 1982 tentang Hukum Laut.

Undang-undang No. 5 Tahun 1983 tentang Zona Ekonomi Eksklusif Indonesia.
Undang-undang No. 17 Tahun 1985 tentang Pengesahan Konvensi PBB 1982 tentang Hukum Laut.

Undang-undang No. 6 Tahun 1996 tentang Perairan Indonesia.

Undang-undang No. 31 Tahun 2004 tentang Perikanan.

Undang-undang No. 27 Tahun 2007 tentang Wilayah Pesisir dan Pulau-pulau Kecil.

UU No. 7 Tahun 2006 tentang Kepabeanan.

UU No. 7 Tahun 2008 tentang Pelayaran. 